\title{
A model of consumer choice with vertically differentiated goods: reassessing the traditional demand theory and an application to tourism
}

[Um modelo de escolha do consumidor com bens diferenciados verticalmente: reavaliação da teoria da demanda tradicional e aplicação ao turismo]

\section{Cristina Barbot*}

University of Porto, Portugal

Submitted 14 Jun 2011; received in revised form 23 Nov 2011; accepted 26 Jan 2012

\begin{abstract}
Standard vertical differentiation models were designed for a type of consumer behaviour when each consumer buys a single unit of only one of two goods. However, in many other cases, consumers may buy a few units of both goods with different qualities. This case is not covered by theory yet. This paper intends to fill this gap, by modelling consumer behaviour and demand with vertical differentiation when all consumers may buy some mix of both qualities. Additionally, we find that two main results of the previous vertical differentiation literature do not apply in this case and show how the model can be extended to a number of situations. We also present an example of how the model may be applied to Tourism and Transport industries.
\end{abstract}

Key words: consumer choice; vertical product differentiation; demand; tourism.

\section{Resumo}

Modelos tradicionais de diferenciação vertical de produto foram projetados para um tipo de comportamento do consumidor quando cada consumidor compra uma única unidade de apenas um dos dois bens. No entanto, em muitos outros casos, os consumidores podem comprar poucas unidades de ambos os bens com qualidades diferentes. Este caso não é coberto pela teoria até o presente momento. Este trabalho pretende preencher esta lacuna, de forma a modelar o comportamento dos consumidores e a demanda com diferenciação vertical de produto quando todos os consumidores podem comprar alguma combinação de ambas as qualidades. Além disso, descobriu-se que dois resultados principais da literatura anterior de diferenciação vertical não se aplicam neste caso e mostrou-se como o modelo pode ser estendido para um número de situações. Apresentamos também um exemplo de como o modelo pode ser aplicado às indústrias Turismo e Transportes.

Palavras-Chave: escolha do consumidor; diferenciação de produto vertical; demanda; turismo.

*Email: cbarbot@fep.up.pt.

\section{Recommended Citation}

Barbot, C. (2013) A model of consumer choice with vertically differentiated goods: reassessing the traditional demand theory and an application to tourism. Journal of Transport Literature, vol. 7, n. 1, pp. 52-64.

- JTL/RELIT is a fully electronic, peer-reviewed, open access, international journal focused on emerging transport markets and published by BPTS - Brazilian Transport Planning Society. Website www.transport-literature.org. ISSN 2238-1031.

This paper is downloadable at www.transport-literature.org/open-access. 


\section{Introduction}

Traditional consumer' demand has been derived through utility maximization under a budget constraint. Considering that all consumers are identical, the aggregation of individual demands leads to the usual demand function for a particular good.

This demand function is built on the assumptions that all consumers have identical tastes and incomes, and that all units of the good are identical. But these assumptions are too strong to fit real consumer behaviour. Consumers often have different tastes or preferences and goods are often different. For example, if we consider the consumption of soft drinks, we may find a great variety of goods, among which consumers choose according to their tastes.

Demand for these situations was first modelled by Launhardt (1993), as Launhardt's work was first published in 1885, in German, and then by Hotelling (1929) and their models are the base of a well-known consumer theory nowadays, the so-called horizontally differentiated goods case. In these models consumers are uniformly distributed along a line, according to their preferences, and they choose the good that is more alike their ideal specification of that product.

Product differentiation may be either horizontal, when all goods have the same quality but consumers differ in their preferences, or vertical, when goods differ in quality and consumers have identical tastes, but differ in their incomes or willingness to pay for quality.

The case of consumer choice for vertically differentiated goods, or of goods that are differentiated by their quality, though consumers exhibit identical preferences but different incomes or different willingness to pay for quality, was modelled much later, in the last quarter of the $20^{\text {th }}$ century. These models were first proposed by Gabszewick and Thisse (1979) and Shaked and Sutton (1982). These authors also consider consumers as uniformly distributed along a line, but according to their willingness to pay for quality, or to their incomes, in the second case. There are a number of goods (often two goods, for simplification) and each consumer buys a single unit of only one the goods (in the situation of 
a "covered" market), or some of them buy nothing at all (in the situation of "uncovered" market).

Gabszewick and Thisse (1979) and Shaked and Sutton (1982), when introducing their models, refer to products such as, and quoting the examples given by the first authors, cars, television sets, washing machines or pianos. All of these are examples of durable goods, which are not very frequently bought, and in one unit in each acquisition. Indeed, people usually do not buy, for example, a dozen of cars a week, or ten washing machines every day. Thus the assumption of each consumer buying only one unit of the goods makes sense.

These models have also became part of consumers' theory, and were often applied for several purposes, namely Minimum quality standars (Scarpa, 1998), or to potential competition (Donnenfeld e Weber, 1995). Indeed, extensions of vertical differentiation theory were rather on firm competition, but never on alternative forms of consumers' behavior. In all of these works the referred assumption of each consumer buying only one unit of the goods was kept.

In what concerns the adequacy of this assumption to real world consumption patterns, our point does not lie in the fact of each consumer buying only one unit of each good. If, instead, she would buy two or more units, results may not be very different. However the model does not apply to all types of goods and to all patterns of consumers' choice. For example, in the case of many other goods, the purchases of which are frequent, consumers often choose several qualities at the same time. A consumer may choose to buy two qualities, a superior and an inferior one, of beef, of fish, of olive oil, or of any other foodstuff. Or she may decide to buy one or several designer suits, but also some cheap pairs of jeans or T-shirts. Many people choose to have everyday lunch in a café or sandwich bar, but they may have dinner in a luxurious restaurant once a week. Or, else, holidaymakers may alternate between five and four or three stars hotels in a single trip. 
So the model for consumers' choice and demand for vertically differentiated goods has to be reassessed in order to capture these situations, which are as common as the ones theory has dealt with, if not more. The purpose of this paper is to do a refinement of the traditional theory by proposing a method to find consumers' demand for the case of vertically differentiated goods when each consumer may buy a bundle that includes more than one good. It intends to fill a gap in literature, as vertical differentiation theory has been established only for the case of durable and not frequently acquired goods. Our result is a simple model that allows for every class of consumers buying both qualities, and which is easy to work with. The model is based on a demand function for each of two goods that allows for the possibility of consumption of both goods by most of the income classes. Additionally, we find that two main results of the previous vertical differentiation literature do not apply in this case, namely that: (i) the higher quality price is not always superior to the lower quality one and (ii) with zero costs the higher quality profits are not always higher.

We develop two extensions of the model, namely for uncovered markets and for demand patterns where consumers do not buy the same number of units of both goods. With a simple application, we show that the model is useful to forecast demand and to develop theoretical works with demand patterns that fit its framework. We also develop an application of the model to Tourism, and show how many a consumer will buy of each of the available qualities, which helps travel agencies to plan their packages.

The paper is structured as follows: section 2 presents the model and in section 3 an application is shown. Section 5 concludes with a few final remarks. 


\section{A model of demand for an alternative consumer behavior}

In our model consumers may acquire two vertical differentiated goods ${ }^{1}$, good 1 and good 2.

Good 2 is recognized by all consumers as having a high quality while good 1 has a lower quality. Let $q_{2}$ stand for the quality of the high quality good, and $q_{1}$ for the low quality one. For simplification, we assume that all costs, including quality costs, are equal to zero, making profits equal to revenues. Prices are denoted by $p_{1}$ and $p_{2}$, respectively.

It is plausible that that the highest their income is, the more consumers will buy the high quality, and less the lowest one. It probably happens that low income consumers never, or only occasionally, buy high quality products, while middle-income consumers alternate qualities, in a fifty percent share, and high income strata buy mostly the highest quality. We follow this assumption in our model.

As in Shaked and Sutton (1982) consumers are uniformly distributed according to their incomes in the interval $[0,1]$, or along a line of length equal to the unit. So, the poorest consumer (or the one who has the lowest willingness to pay for quality) is situated at point " 0 " and the richest consumer (or the one who has the highest willingness to pay for quality) is situated in pint " 1 ". Each consumer may buy zero, $n$ or any quantity in the interval $[0, n]$ of each one of the two goods. Then the market is covered in the sense that all consumers buy $n$ units of one or of both goods. Their utility function follows the usual specification of vertical differentiation theory, as may be found in Shaked and Sutton (1982), but allowing for this consumption pattern:

$$
U=k u_{1} t_{j}+(n-k) u_{2} t_{j}, j=1,2, \ldots, n
$$

\footnotetext{
${ }^{1}$ Some papers have used vertical differentiation in Transport, as in Barbot (2004), Barbot (2008) and Vassalo (2010).
} 
$u_{1}$ and $u_{2}$ standing for the utility derived from the consumption of one unit of the goods 1 and $2, t_{j}$ for the income, net of the expense in the vertically differentiated goods, and $k$ for the number of units each consumer buys of the low quality good.

So the total utility of a consumer is equal to the sum of utility derived from the consumption of $k$ units of good 1 and $n-k$ units of good 2, multiplied by the remaining income (when the expense in these goods is deduced), that represents the utility of consuming all other (other than $q_{1}$ and $q_{2}$.) goods $\left(t_{j}=\left(k p_{1}+(n-k) p_{2}\right)\right.$.

Considering that utility is linearly related to the quality $q_{i}, u_{i}=a q_{i}$, and with $a=1$, the utility function may also be written as:

$$
U=k q_{1} t_{j}+(n-k) q_{2} t_{j}
$$

The game has two stages. In the first stage firms choose qualities and in the second stage they compete in prices. The main point here is to find the demand for the vertically differentiated goods. To compute the demand for each good we consider consumers as divided into income classes with identical consumption patterns as follows. The lowest income class will only buy $q_{1}$. The next income class will buy $n-1$ units of $q_{1}$ and one unit of $q_{2}$. The third income class will buy $n$-2 units of $q_{1}$ and two units of $q_{2}$. And so forth. The highest income class will buy $n$ units of $q_{2}$, while the previous class will buy a mix of $n-1$ units of $q_{2}$ and one unit of $q_{1}$.

Next we find the income limits of each class. The consumer who is indifferent between $n$ units of $q_{1}$ and zero units of $q_{2}$, and a bundle of $n$ - 1 units of $q_{1}$ and one unit of $q_{2}$ follows the indifference condition:

$$
n q_{1}\left(t_{1}-n p_{1}\right)=\left((n-1) q_{1}+q_{2}\right)\left(t_{1}-\left((n-1) p_{1}+p_{2}\right)\right)
$$

Then the consumer indifferent between this last bundle and $n$ - 2 units of $q_{1}$ combined with 2 units of $q_{2}$ is represented by:

$$
\begin{aligned}
& \left((n-1) q_{1}+q_{2}\right)\left(t_{2}-\left((n-1) p_{1}+p_{2}\right)\right) \\
= & \left((n-2) q_{1}+2 q_{2}\right)\left(t_{2}-\left((n-2) p_{1}+2 p_{2}\right)\right)
\end{aligned}
$$


And so forth. Finally, the consumer dividing the two last income classes is indifferent between the bundle containing one unit of $q_{1}$ and $n-1$ of $q_{2}$, and $n$ units of $q_{2}$ :

$$
\left(q_{1}+(n-1) q_{2}\right)\left(t_{n}-\left(\left(p_{1}+(n-1) p_{2}\right)\right)=n q_{2}\left(t_{n}-n p_{2}\right)\right.
$$

The above equations are then solved for $t_{1}, t_{2}, \ldots, t_{n}$.

It follows that consumers whose income is inferior to $t_{l}$ will only buy the lowest quality, while those whose income lies between " 1 " and $t_{n}$ will only buy $q_{2}$.

The demand of the first segment, or of those who buy only $q_{1}$, lies between $t_{1}$ and " 0 ". We first find $t_{l}$ by using the equation (3):

$$
\frac{q_{1} p_{2}(n-1)-q_{1} p_{1}(2 n-1)+q_{2} p_{1}(n+1)+q_{2} p_{2}}{q_{2}-q_{1}}
$$

This value of $t_{1}$ minus zero (where the first consumer is situated) is the first part of $X_{1}$, the demand for $q_{1}$. We also find the first part of $X_{2}$, the demand for $q_{2}$, by subtracting from the unit (where the last consumer is situated) the value of $t_{n}$, found by solving equation (5).

Consumers belonging to all the other income segments buy a mix of both qualities. Computing the differences: $t_{2}-t_{1}, t_{3}-t_{2}, \ldots, t_{n-2}-t_{n-1}$ and $t_{n}-t_{n-1}$, which express demands of all other segments, it results that those differences are all equal to $2 p_{2}-2 p_{1}$, meaning that in each income class there are $2 p_{2}-2 p_{1}$ consumers. $X_{1}$, the demand for $q_{1}$ equals the sum of the first market segment - those consuming only this quality - multiplied by $n$, the quantity each consumer buys, plus $n-1$ factors, which correspond to the middle strata demands.

The addition of these factors will be equal to $2 p_{2}-2 p_{1}$ multiplied by the sum of an arithmetical progression:

$$
\begin{aligned}
& 2\left(p_{2}-p_{1}\right)(n-1)+2\left(p_{2}-p_{1}\right)(n-2)+\ldots+2\left(p_{2}-p_{1}\right)+t_{1}=\frac{n(n-1)}{2} 2\left(p_{2}-p_{1}\right) \\
& \text { and } X_{1}=\frac{q_{1} p_{2}(n-1)-q_{1} p_{1}(2 n-1)+q_{2} p_{1}(n+1)+q_{2} p_{2}}{q_{2}-q_{1}}+\frac{n(n-1)}{2}\left(p_{2}-p_{1}\right)
\end{aligned}
$$




$$
X_{1}=n^{2} \frac{p_{2} q_{2}-p_{1} q_{1}}{q_{2}-q_{1}}
$$

Demand for $q_{2}$ is also computed in a similar way, by adding the demand of the highest income class to the same factor $\frac{n(n-1)}{2} 2\left(p_{2}-p_{1}\right)$ :

$$
X_{2}=n \frac{q_{2}-q_{1}+n\left(p_{1} q_{1}-p_{2} q_{2}\right)}{q_{2}-q_{1}}
$$

The main purpose of this paper was to find the expressions of these demands. However we solve the rest of the model.

Under the assumptions of zero costs, profits are equal to revenues, or $\pi_{1}=p_{1} X_{1}$ and $\pi_{2}=p_{2} X_{2}$, where $\pi_{1}$ and $\pi_{2}$ are the profits of firms that produce, respectively, goods 1 and 2 . These firms compete in prices, as in the models of Gabszewick and Thisse (1979) and Shaked and Sutton (1982). In this Bertrand game ${ }^{2}$, firms maximize their profits in $p_{1}$ and $p_{2}$, respectively, from where their best reply functions are derived. Solving these functions, we find the expressions of prices, depending on $q_{1}, q_{2}$ and $n$.

Solving the second stage Bertrand game there result solutions for prices, demands and profits as expressions depending on the qualities and on $n$, the number of units bought by each consumer:

$$
\begin{gathered}
p_{1}=\frac{q_{2}-q_{1}}{3 n q_{1}} ; \quad p_{2}=\frac{2\left(q_{2}-q_{1}\right)}{3 n q_{2}} \\
X_{1}=\frac{1}{3 n} ; X_{2}=\frac{2}{3 n}
\end{gathered}
$$

${ }^{2}$ Many authors used Bertrand competition in Transport research, as in Oliveira (2010) and Silveira e Oliveira (2008) 


$$
\pi_{1}=\frac{q_{2}-q_{1}}{9 q_{1}} ; \pi_{2}=\frac{4\left(q_{2}-q_{1}\right)}{9 q_{2}}
$$

Thus it is possible to model vertical differentiation for this type of consumer behaviour, when she buys both qualities (or both goods). The model may be easily completed in the first stage, by maximizing profits in qualities and finding solutions for $q_{1}$ and $q_{2}$. However, the main issue of this paper is to show how demands for vertically differentiated goods which are bought in bundles can be computed. The other interesting point of this paper is that some results of vertical differentiation theory with durable goods do not apply to the present case.

In order to analyse these different results, we present the solutions of the simplest model for durable goods, where each consumer buys one unit of only one of the two goods ${ }^{3}$, and also with zero costs:

$$
\begin{gathered}
p_{1}=q_{1} \frac{q_{2}-q_{1}}{4 q_{2}-q_{1}} ; p_{2} 2 q_{2} \frac{q_{2}-q_{2}}{4 q_{2}-q_{1}} \\
\pi_{1}=2 q_{1} \frac{q_{2}-q_{1}}{\left(4 q_{2}-q_{1}\right)^{2}} ; \pi_{1}=2 q_{2}^{2} \frac{q_{2}-q_{1}}{\left(4 q_{2}-q_{1}\right)^{2}}
\end{gathered}
$$

Two main results are worth stressing here:

1) With durable goods the price of the high quality is always higher (Shaked and Sutton, 1992). However, in the case of nondurable goods it happens that $p_{2}>p_{1}$ if only if $q_{2}<2 q_{1}$. The price of the best quality will only be higher if qualities are near enough.

\footnotetext{
${ }^{3}$ These results are well known and have been established in several ways. Here, we follow Motta [2], but withdraw the quality costs.
} 
2) In the durable goods case and with zero costs, the highest quality firm has always higher profits (Shaked and Sutton, 1992). With nondurable goods this result only applies if $q_{2}<4 q_{1}$. Consumers in the middle strata of income, who buy some units of both goods, always buy $2\left(p_{2}-p_{1}\right) j, j=1,2, \ldots n$ units of one good and $2\left(p_{2}-p_{1}\right)(n-j)$ units of the other. With very different qualities, $p_{2}$ would be too high and these consumers prefer to buy $q_{1}$.

The model can be easily adapted to a case of uncovered market, when some consumers do not buy even a single unit of $q_{1}$. In this case, in the firsts segment, the consumer indifferent between acquiring $\mathrm{n}$ units of $q_{1}$ or nothing at all is represented by:

$$
n q_{1}\left(t_{1}-n p_{1}\right)=0 \text {, with } t_{1}=n p_{1}
$$

We compute the demand for $\mathrm{X}_{1}$ in the same way, only that the first segment now buys only $n\left(\mathrm{t}_{2}-n p_{1}\right)$ units of $q_{1}$. Proceeding in the same way as before, we compute quantities, prices and profits:

$$
\begin{gathered}
p_{1}=\frac{q_{2}-q_{1}}{n\left(4 q_{2}-q_{1}\right)} ; p_{2}=2 \frac{q_{2}-q_{2}}{n\left(4 q_{2}-q_{1}\right)} \\
X_{1}=n \frac{q_{2}}{\left(4 q_{2}-q_{1}\right)} ; X_{2}=2 n \frac{q_{2}}{\left(4 q_{2}-q_{1}\right)} \\
\pi_{1}=q_{2} \frac{q_{2}-q_{1}}{\left(q_{1}-4 q_{2}\right)^{2}} ; \pi_{2}=4 q_{2} \frac{q_{2}-q_{1}}{\left(q_{1}-4 q_{2}\right)^{2}}
\end{gathered}
$$

If the market is not covered, it always happens that $p_{2}>p_{1}$ and $\pi_{1}>\pi_{2}$.

Also, we could suppose the first segment of demand was divided in the following way: some consumers buy zero units of $q_{1}$, others one unit of this good, others two units, and so forth, up to the last consumer in this segment, who buys $n$ units of $q_{1}$.

The indifferent consumers in the first segment are represented by $k q_{1}+\left(t_{i}-k p_{1}\right)=(k+1) q_{1}+t_{i^{-}}$ $(k+1) p_{1}$, with $k=0,1,2, \ldots, n$, and where $k$ is the number of units of $q_{1}$ they wish to buy. Solving the expression, $t_{k}=(1+2 k) p_{1}$, the demand of $q_{1}$ from this first segment will be $X_{1}=2$ 
$p_{1}\left(1+2+\ldots+(n-1)+\left(t_{1}-2 p_{1}\right) n\right.$, where is the consumer indifferent between buying $n$ units of $q_{1}$ or $n$ units of $q_{1}$ and one unit of $q_{2}$. We would then compute results as in the previous cases.

This process can be adapted to any other demand segment, and to all of them, either the consumers wish to acquire zero, one, two, up to $k$ units of good 1 , or of good 2, or of both. Extending the process to all demand classes and to both goods introduces more generality in the model, but solutions become more and more complex, and difficult to deal with. Moreover, in real life consumers usually buy $n$ units of a single quality or of both. We next present an application of this model.

\section{Application to Tourism}

Suppose that a travel agent is designing a weekly package and choosing the hotels to book. The package consists of flight and accommodation for seven nights in different cities.

She knows the demand for the package is of 100 consumers, who are uniformly distributed according to the consumers' income (or willingness to pay for quality). According to the price of the whole package, she also knows that travelers will accept three stars (quality $q_{1}$ ) or four stars (quality $q_{2}$ ) hotels. Suppose that, for simplicity, there are only two hotels, one of each class, in all the visited cities, and that they only have this demand every week.

With 800 travelers, in one week, 5600 rooms must be booked. The travel agent's problem is to decide how many rooms she should book in each one of the hotels. There are eight groups of tourists, each composed of 100 persons: those who sleep all the seven nights in three stars, then those who sleep six nights in three stars and one night in four stars, and so on, the last group being travelers who sleep seven nights in four stars. Applying our results, presented in Table 1, the travel agent should book 2800 nights in three stars, and 2800 nights in four stars, or, in each city, the same number divided by seven. Prices would depend on the qualities, which had been already chosen. 
Table 1: Example for Tourism

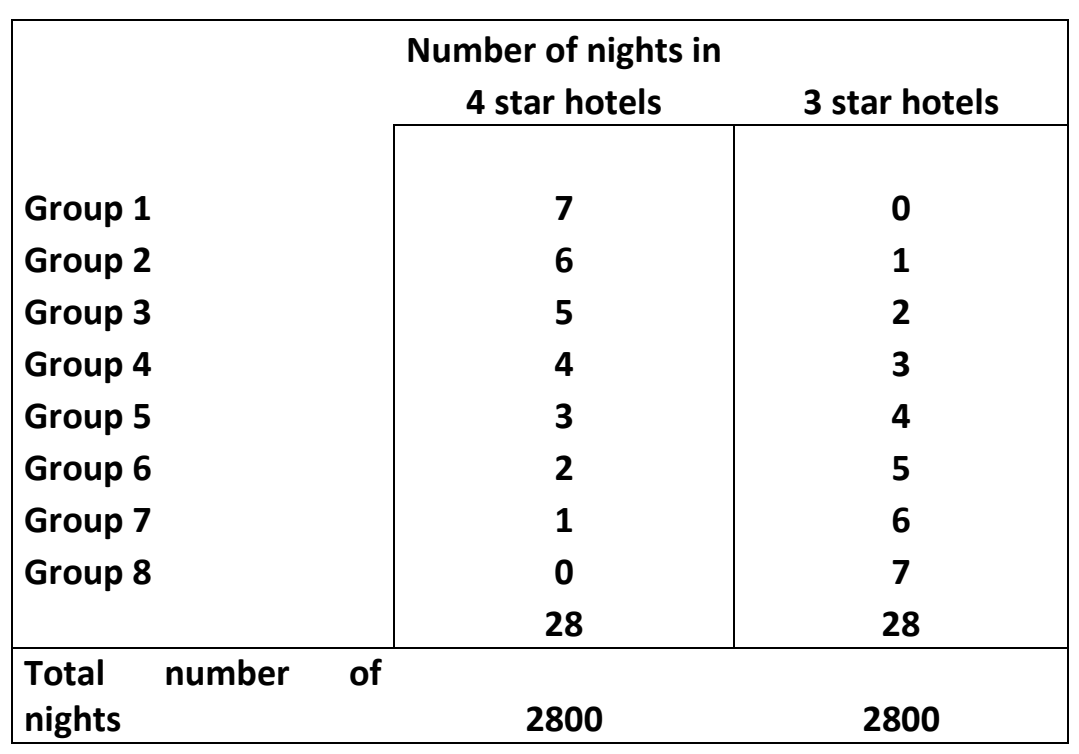

This simple application shows that the model of this paper is useful to forecast demand and determine prices. In this case, qualities were previously chosen. The model may also predict how much it is worth to invest in improving quality, with sunk costs.

The model may be applied to any good of service since consumers buy several qualities. In Air Transport, passengers may book long haul flights in executive class (high quality) and complementary short haul segments in economy class (lower quality).

\section{Concluding remarks}

In this paper we build a model to determine demands and prices when vertically differentiated goods are consumed in bundles. The model is applicable to a number of situations, by redefining demand classes. We intend to fill a gap in literature, since vertical differentiation models, up to now, were built under the assumption that each consumer acquires a unit of a single quality. As we show above, results may differ from the existing literature ones. So, we expected to have provided future research with a new demand model, which may be used in a variety of situations that fit this type of consumer behavior. 


\section{References}

Barbot, C. (2004) Economic effects of re-allocating airports slots: A vertical differentiation approach. Journal of Air Transport Management, vol. 10, pp. 333-343.

Barbot, C. (2008) Can low cost carriers deter or accommodate entry? Transportation Research Part E, vol. 44, pp. 883-893.

Donnenfeld, S. and S. Weber (1995) Limit Qualities and Entry Deterrence. RAND Journal of Economics, vol. 26 (Spring), pp. 113-130.

Gabszewick, J. and Thisse, J. F. (1979) Price competition, quality and income disparities. Journal of Economic Theory, vol. 20 (June), 340-359.

Hotelling, H. (1929) Stability in Competition. Economic Journal. vol. 39 (March), pp. 41-57.

Launhardt, W. (1993) Principles of Mathematical Economics, Edward Elgar, Gloucester.

Motta, M. (1993) Endogenous quality choice: Price versus quantity competition, Journal of Industrial Economics, vol. XLI (June), pp. 113-131.

Oliveira, A. (2010) A Alocação de Slots em Aeroportos Congestionados e suas Consequências no Poder de Mercado das Companhias Aéreas. Journal of Transport Literature, vol. 4, n. 2, pp. 5 49.

Scarpa, C. (1998) Minimum Quality Standards with More than Two Firms. International Journal of Industrial Organisation, vol. 16 (September), pp. 665-676.

Shaked, A. and J. Sutton (1982) Relaxing price competition through product differentiation. Review of Economic Studies, vol. 49 (January), pp. 3-13.

Silveira, J. M. and Oliveira, A. V. M. (2008) An Empirical Game-Theoretical Approach to Model a Price War in the Brazilian Airline Industry. Journal of Transport Literature, vol. 2, n. 1, pp. 7 20.

Vassallo, M. D. (2010) Simulação de Fusão com Variações de Qualidade no Produto das Firmas: Aplicação para o Caso do Code-Share Varig-TAM. Journal of Transport Literature, vol. 4, n. 2, pp. 50-100. 